Martin Eriksson är gymnasielärare i biologi, kemi och naturkunskap vid Mikael Elias teoretiska Gymnasium i Norr-

köping.

Carl-Johan Rundgren är lektor vid institutionen för matematikämnets och naturvetenskapsämnenas didaktik vid

Stockholms universitet. Han disputerade i naturvetenskapernas didaktik vid Linköpings universitet 2008 och har varit

föreståndare för FontD (Nationella Forskarskolan i Naturvetenskapernas, Teknikens och Matematikens Didaktik) fram

till sommaren 2011.

\title{
MARTIN ERIKSSON
}

Norrköping, Sverige

martin.eriksson@teoretiska.se

\section{CARL-JOHAN RUNDGREN}

Institutionen för matematikämnets och naturvetenskapsämnenas didaktik vid Stockholms universitet, Sverige

carl-johan.rundgren@mnd.su.se

\section{Vargfrågan}

\section{- Gymnasieelevers argumentation kring ett sociovetenskapligt dilemma}

\begin{abstract}
The focus of this study is the attitudes towards wolves in Sweden among upper secondary students. This socio-scientific issue (SSI) involves many aspects, such as ethical, political and biological aspects, and provides a context to study students' informal argumentation. The different arguments used by the students were analyzed using the framework of the SEE-SEP-model. A questionnaire probing attitudes to the existence of wolves in the neighbourhood was distributed to 352 upper secondary students. 18 students were interviewed in focused group-interviews (in pairs). The results showed that $55 \%$ of the students showed a negative attitude towards the existence of wolves in the neighbourhood. The analysis of the different aspects of arguments used by the students in the interviews showed that arguments based on value were more dominant (60\%) than arguments based on knowledge (30\%), and arguments based on personal experiences (10\%).
\end{abstract}

\section{INLEDNING}

I denna artikel studeras gymnasieelevers argumentation kring förekomst av varg i Sverige ur ett SSI-perspektiv. SSI står för Socio-Scientific Issues (Zeidler, Sadler, Simmons \& Howes, 2005), vilket innebär aktuella samhällsfrågor som relaterar till naturvetenskaplig kunskap men som också inbegriper etiska och andra aspekter och där givna lösningar med rätta svar saknas. Vi använder här sociovetenskapliga dilemman som svensk beteckning för SSI.

\section{STS, SSI och naturvetenskap som allmänbildning}

Under senare delen av 1970-talet och början av 1980-talet startades fler och fler forskningsprojekt som handlade om att koppla skolans naturvetenskap till teknologi och samhälle. Inom forskningen växte det fram en gemensam betoning på att elever skulle uppfatta undervisningen i naturvetenskap som mer relevant och meningsfylld om den visade hur naturvetenskapen påverkar utvecklingen av ny teknologi, och hur teknologin sen i sin tur påverkar samhället. Denna betoning 
på en växelverkan mellan naturvetenskap, teknik och samhälle, har samlats under begreppet STS, som står för "Science-Technology-Society" (Aikenhead, 1994).

Mot bakgrund av att skolans NO-ämnen fått kritik om sig att vara för abstrakta och teoretiska, och upplevts vara för mycket inriktade mot förberedelser för högre akademiska studier och därmed ha bristande relevans för de flesta elever (Millar, 2008), har STS-tanken goda ansatser. STS har lyfts fram som ett sätt att uppnå målet med en ökad allmänbildning inom naturvetenskap (s.k. "scientific literacy"). Med ett ökande fokus på miljöfrågor i samhället har miljön betonats som en enskilt viktig del i sambandet mellan vetenskap, teknologi och samhälle, under beteckningen STSE (Science-Technology-Society-Environment). STSE är en vidareutveckling av STS, och tillför ett perspektiv på hållbar utveckling i frågeställningar kring naturvetenskap och samhälle. Men på senare år har det även växt fram en del kritik mot STS(E). Trots att STS(E) haft stor genomslagskraft och tydligt framkommer i styrdokument, läro- och kursplaner för NO-ämnen, inte minst i Skandinavien, har den praktiska tillämpningen i klassrummet varit ganska diffus. Zeidler et al. (2005) framhåller att STS(E)-inslagen ofta består av enstaka isolerade projekt och utspridda små färgade textrutor som bredvidläsning i läroböcker. Många STS-baserade projekt (exempelvis kring energianvändning, klimatförändringar etc.) verkar också ha problem med att inte framstå som tillräckligt intressanta och relevanta för eleverna, eftersom de sällan berör ungdomarnas personliga intressen och livserfarenheter (Shamos, 1995). STS(E)-undervisning saknar dessutom ofta tydligt fokus på de etiska dimensioner som kan förekomma vid diskussioner och ställningstaganden om vetenskap och samhälle. Elevernas moraliska ställningstaganden och personliga utveckling lyfts inte heller fram som något betydelsefullt. Med utgångspunkt från denna kritik har ett nytt begrepp vuxit fram, sociovetenskapliga dilemman (SSI), som representerar en utveckling av STS-modellen (Zeidler et al., 2005).

Medan huvudsyftet med STS-orienterad undervisning är att öka elevernas medvetenhet och intresse för naturvetenskap genom att placera det naturvetenskapliga innehållet i en social kontext, är syftet med SSI-undervisning, utöver en ökad medvetenhet om kopplingen mellan naturvetenskap och samhälle, att stimulera elevernas individuella intellektuella utveckling i moraliska och etiska ställningstaganden. SSI-orienterad undervisning innebär alltså olika ställningstaganden runt etiska frågor och utvecklandet av moraliska ståndpunkter i olika diskussioner i samhällsfrågor med naturvetenskaplig koppling. När NO-undervisningen baseras på SSI kan den naturvetenskapliga kunskapen placeras in i elevernas sociala, politiska, och kulturella liv, på ett mer djupare personligt plan än när det gäller STS. Ratcliffe \& Grace (2003) har beskrivit ett antal karaktäristiska kännetecken för SSI-frågor: De är aktuella frågor som är viktiga för samhället och har alltid en grund i naturvetenskap, innebär ställningstaganden och olika val på personlig och social nivå, är ofta förekommande i media, innehåller ofullständig och motsägande information på grund av intressekonflikter och ofta ofullständiga vetenskapliga bevis, verkar på lokal, nationell och global nivå med viktiga politiska och sociala effekter, kan kräva viss användning av riskanalyser, kan innehålla frågor om hållbar utveckling, innehåller värderingar och ställningstaganden i etiska frågor, innebär ofta någon form av "cost-benefit"-analys, och det finns ingen given lösning med rätta svar (Ratcliffe \& Grace, 2003).

\section{Naturvårdsfrågor - ett lämpligt sammanhang att träna argumentation}

Att träna förmågan att argumentera har framhållits som ett viktigt mål för NO-undervisningen (Driver, Newton \& Osborne, 2000). Sadler, Barab \& Scott (2007) betonar att SSI, genom att befrämja förmågan att argumentera i grupp, också kan få effekter som ett utvidgat naturvetenskapligt (kritiskt) tänkande, bättre förmåga att fatta vetenskapligt underbyggda beslut, och större medvetenhet om hur naturvetenskapen fungerar som process och dess förklaringsmöjligheter och begränsningar. Elever kan också, genom diskussion av SSI-frågor, tillägna sig kunskap om olika naturvetenskapliga begrepp, teorier och förklaringsmodeller. 
Naturvårdsfrågor rörande bevarande av den biologiska mångfalden innebär ofta svåra ställningstaganden och beslut. Långsiktigt framgångsrika artbevarandeprojekt bygger ofta på ett multiperspektiv, där ekonomiska, politiska, kulturella, etiska, och även estetiska värden utgör viktiga faktorer jämsides med kunskaper om biologisk mångfald, ekologi etc. Flera studier (Grace, \& Ratcliffe, 2002; Mork, 2005; Grace, 2009; Lee \& Grace, 2010) finns om elevers argumentation och beslutsfattande i sociovetenskapliga dilemman om naturvårdsbiologi. Grace (2009), som har studerat elevers argumentation kring bevarandefrågor och viltvård, betonar att förmågan att argumentera om och ta ställning till bevarandefrågor ger en bra grund för fortsatta ställningstaganden i en mängd olika frågor om hållbar utveckling. I Norden har Mork analyserat elevers argumentation och lärande utifrån ett program inom Viten-projektet, som behandlar vargfrågan i Norge (Mork, 2005 och 2006). Den föreliggande studien använder vargfrågan i Sverige för att studera gymnasieelevers argumentation kring ett sociovetenskapligt dilemma inom naturvård och bevarande av biologisk mångfald.

\section{SEE-SEP-modellen}

Som ett verktyg för att analysera elevers argumentation används här SEE-SEP-modellen (Chang Rundgren \& Rundgren, 2010), som ger ett holistiskt perspektiv på vad SSI står för. I SEE-SEPmodellen har tre aspekter identifierats: "value" (värderingar), "personal experiences" (personliga erfarenheter), och "knowledge" (kunskap), som viktiga faktorer (se figur 1), vilka ligger till grund för individers argumentation om SSI. Vidare kan dessa tre aspekter knytas till sex olika beskrivna ämnesområden: samhälle/kultur (sociology/culture) (S), miljö (environment) (E), ekonomi (economy) (E), naturvetenskap (science) (S), etik/moral (ethics/morality) (E) and lagar/förordningar (policy) (P), (vars förkortningar alltså bildar själva namnet på modellen). Till dessa ämnesområden kopplas i modellen de tre aspekterna: value, personal experiences, och knowledge, som genom tidigare studier visat sig vara viktiga huvudfaktorer vid elevers argumentering och ställningstagande i olika SSI. De tre aspekterna kan tillsammans förkortas KVP. Chang Rundgren \& Rundgren (2010) betonar att beroende på frågeställningen i ett SSI berörs olika ämnesområden olika mycket och därför behöver inte alltid alla sex ämnesområden och alla tre aspekter involveras i argumenteringen kring en specifik SSI-fråga.

Aspekten "value" kan närmast översättas till "värdering" och innebär som aspekt i SEE-SEP-modellen människors värderingar och känslomässiga attityder, vilka är starkt kopplade till individens sociokulturella bakgrund (religion, kultur, familj, skolan o.s.v.). Tidigare studier av elevers argumentering kring SSI-frågor har visat att det är mycket vanligt att använda egna värderingar och känslomässiga attityder vid beslutsfattande kring olika SSI, speciellt när det finns lite eller otydliga och motsägelsefulla faktamässiga beslutsunderlag (Chang Rundgren, 2011a). Aspekten "personliga erfarenheter" anknyter till erfarenheter som har hämtats från andra sammanhang än det formella utbildningssystemet. Exempelvis kan erfarenheter från familjeliv, samhällsliv, yrkesliv och även media räknas hit. I likhet med studier som påvisar människors användning av känslomässiga attityder vid beslutsfattande har även personliga erfarenheter visats ha en betydelse för ställningstagandet kring olika SSI. Detta gäller speciellt när det saknas tillförlitligt faktaunderlag för ett specifikt SSI. Ju mer ett SSI är kopplat till människors vardagsliv, desto större roll verkar också personliga erfarenheter ha på argumentationen (Chang Rundgren, 2011a). Kunskapsaspekten har diskuterats i flera studier (bl.a. Ekborg, 2002; Grace \& Ratcliffe, 2002; Sadler \& Zeidler 2005; Sadler \& Donnelly, 2006), vilka pekar på en avsaknad av ett entydigt samband mellan en individs ämneskunskaper och förmågan att argumentera och tillämpa dessa kunskaper för genomtänkta ställningstaganden i olika SSI-frågor.

Clement $(2004,2006)$ har skapat en modell för att analysera olika aspekter av ett begrepp enligt ett KVP-schema, där K står för vetenskaplig kunskap (connaissences scientifiques), V för värderingar (valeurs) och P för sociala praktiker (pratiques sociales). En skillnad mellan denna modell och SEE-SEP är att Clements modell analyserar begrepp (conceptions), medan SEE-SEP-modellen är 


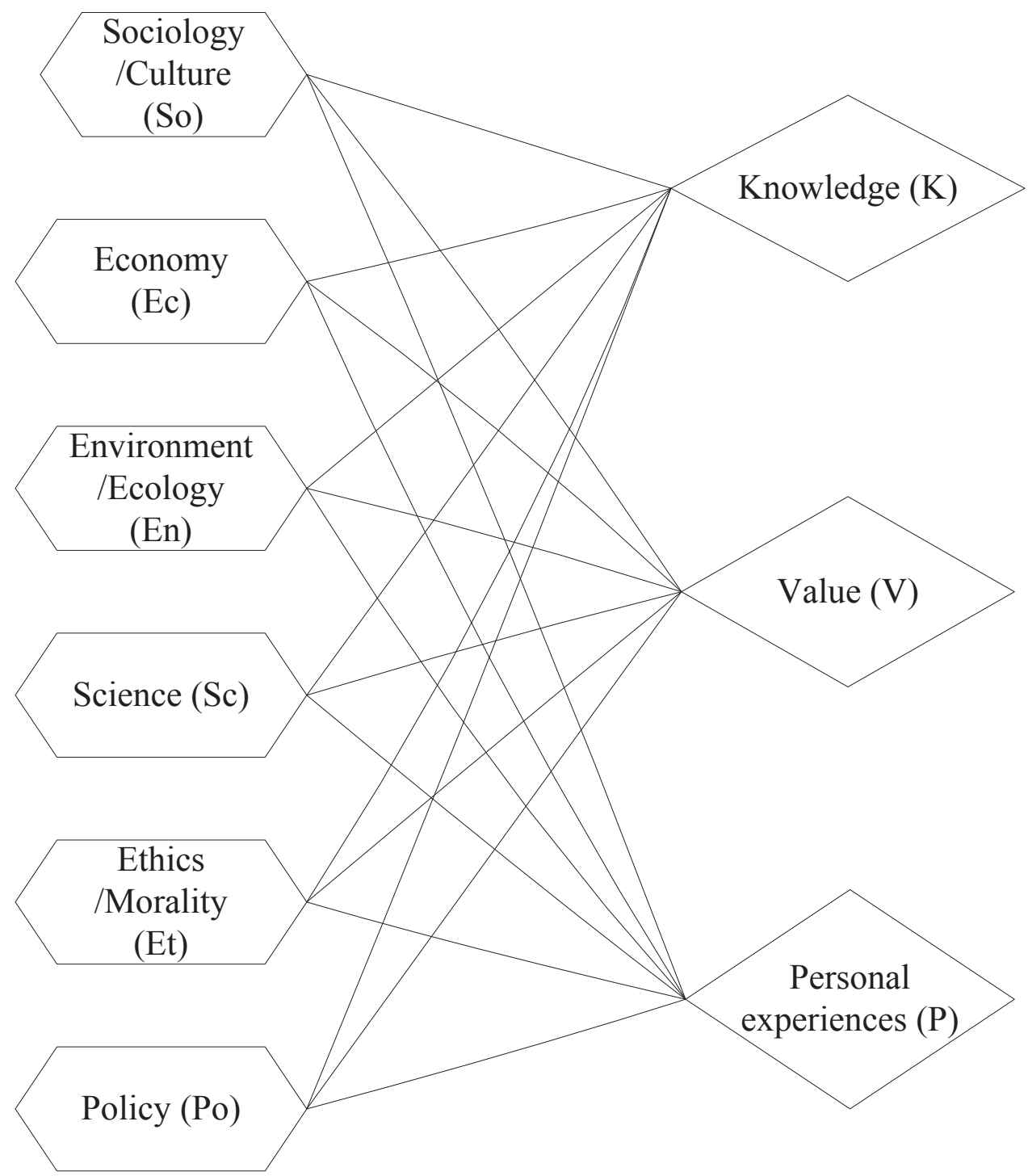

Figur 1. SEE-SEP-modellen - ett holistiskt perspektiv på SSI (Efter Chang Rundgren, \& Rundgren, 2010).

konstruerad i syfte att analysera argument som individer använder i en argumentation. Ytterligare en skillnad är att dimensionen P skiljer sig åt i de två modellerna, eftersom P i Clements KVPmodell knyter till en social nivå och beskriver sociala praktiker, medan P i SEE-SEP står för individens erfarenheter. SEE-SEP-modellen har nyligen använts av Christenson, Chang Rundgren \& Höglund (in press) för att analysera gymnasieelevers skrivna argumentation kring fyra SSI (global uppvärmning, GMO, kärnkraft och konsumtion).

\section{Vargar i Sverige}

Frågan om vargar i Sverige har debatterats under längre tid och i hög grad uppmärksammats i media. Kontexten för detta sociovetenskapliga dilemma täcker in många olika ämnesområden och 
aspekter, och överensstämmer med de SSI-karakteristiska som formulerats av Ratcliffe \& Grace (2003). Vikten av ökad kunskap om hur människor hanterar aktuella samhällsfrågor med naturvetenskapligt innehåll, som figurerar i media, har betonats i flera vetenskapliga studier (Kolstø, 2001; Rundgren, Chang Rundgren, Lin, Tseng \& Chang, in press).

Under den senaste tiden har medierapporteringen fokuserat på framför allt vargrivna tamdjur, licensjakt, illegal vargjakt, och inplantering av nya vargar. Vargen fridlystes i Sverige så sent som 1966, då det bara existerade ett fåtal djur, troligen färre än tio vargar. Fram till dess hade staten bidragit till utrotningen genom att betala ut skottpengar. Efter en långsam ökning i antal under 1980-talet har vargen i Skandinavien nu börjat återta sina gamla jaktmarker. I dag uppgår det totala antalet vargar i Sverige till mellan 174 och 208 vargindivider, och är koncentrerade till framför allt Västra Götalands län, Värmland, Dalarna, och Gävleborgs län (Svensson \& Hedmark, 2010). Sverige har skrivit på internationella överenskommelser och förbundit sig att ta fullt ansvar för alla de arter som är naturligt förekommande här. Sveriges riksdag har i sitt beslut om en sammanhållen rovdjurspolitik 2001 slagit fast att de stora rovdjuren björn, järv, lodjur, varg och kungsörn hör hemma i den svenska naturen och ska långsiktigt bevaras i den svenska faunan. När regeringen beslutade att införa licensjakt 2010 på 27 vargar, väckte beslutet stor debatt i dagstidningar, TV, och sociala medier. Många olika intresseorganisationer är inblandade i debatten, framför allt olika jägar- och miljöorganisationer.

Vargfrågan debatteras på många olika nivåer i samhället och verkar även beröra många människor på ett mer personligt plan. I en intervjuundersökning från 1999 (Karlsson, 1999) om svenskarnas inställning till varg sa sig $69 \%$ av de tillfrågade kunna acceptera en vargstam på åtminstone 100200 vargar och 41 \% kunde acceptera en stam på åtminstone 500-1000 vargar i hela landet. Personer boende i områden som saknar vargrevir var något mer positiva till varg än personer som bor i vargtäta områden. Ålder spelade också roll för inställningen till varg, där yngre människor (15-29 år) hade en mer positiv inställning än äldre personer. Skillnader hittades också mellan könen, då män var överlag mer positivt inställda till vargar än kvinnor i motsvarande ålder. Till exempel svarade $74 \%$ av männen mellan 15 och 29 år att de kunde acceptera att ha varg i närheten av platsen där de bor jämfört med $56 \%$ bland kvinnor i samma åldersgrupp. Totalt sa sig $43 \%$ av de tillfrågade att de inte kunde acceptera att ha varg i närheten av platsen där de bor (Karlsson, 1999). I en något senare undersökning av Karlsson \& Sjöström (2007) hittades ett signifikant samband mellan avståndet till närmaste vargrevir och attityder till varg. Ju längre bort från vargrevir som människor bor, desto mer positiva är de till att bevara vargar. En enkätundersökning från Sveriges lantbruksuniversitet (SLU) (Sandström \& Ericsson, 2009), som utfördes under 2009, visade att i kommuner med vargrevir är rädslan för varg ofta starkare än i kommuner där det inte finns vargrevir, exempelvis ansåg sig 36 \% av invånarna i Dalarna och 34 \% av invånarna i Gävleborg, båda län med relativt hög täthet av vargrevir, vara rädda för varg jämfört med $25 \%$ för riket i genomsnitt.

Vad som än beslutas i frågan på politisk nivå upplever uppenbarligen en del människor, speciellt i närheten av vargrevir, att det finns problem med varg i bebodda områden. Trots ändringar i lagstiftningen med större möjligheter till skyddsjakt och licensjakt finns det människor som är mycket missnöjda med vargens närvaro och oroade över att konflikterna kan komma att öka mellan människa och varg. Tamdjursägare kan drabbas och känner oro för sina djur. Jägare klagar på att jakten på annat vilt drabbas negativt och att deras lösspringande jakthundar riskerar att skadas eller dödas p.g.a. vargangrepp. Vargens farlighet för enskilda människor har också lyfts fram, och det finns ett fåtal historiskt dokumenterade fall där både barn och vuxna blivit skadade eller dödade av friska vargar (Linell \& Bjerke, 2002). Många av dessa angrepp anses kunna kopplas till att vargen blivit för orädd på grund av att den inte jagats i området. En del propagerar bland annat därför för fri vargjakt i mer befolkade områden. Vargens möjligheter att överleva i Sverige i dag beror helt och hållet på om vi människor vill dela med oss av livsrum och skogens bytesdjur. 
Denna aktuella naturvårds-/viltvårdsfråga är ett bra exempel på ett sociovetenskapligt dilemma där argument bör kunna hämtas från de tre aspekterna värderingar, personliga erfarenheter samt kunskap, i kombination med alla de sex ämnesområdena i SEE-SEP-modellen (Chang Rundgren \& Rundgren, 2010). Naturvetenskaplig kunskap som är tillämpbar på detta SSI handlar framför allt om ekologi och miljövård (populationsekologiska samspel, samhällsekologi, beteendeekologiskt om vargens och hundens beteenden, betydelsen av biologisk mångfald etc.). Huvudsyftet med denna undersökning är att försöka få fram mer kunskap om hur gymnasieelevers ställningstagande och argumentering ser ut, speciellt i förhållande till användande av naturvetenskaplig kunskap, när de konfronteras med ett sociovetenskapligt dilemma inom naturvårdsbiologi.

\section{Frågeställningar}

- Vilken attityd har gymnasieelever till förekomst av varg i närområdet?

- Vilka argument använder gymnasieelever i sin argumentation kring vargfrågan?

- Vilka argument är av störst betydelse för elevernas argumentation kring vargfrågan?

\section{Metod}

För att inledningsvis få en översiktlig bild av gymnasieelevers attityder i frågan om vargar i Sverige, fick totalt 23 klasser, från fem olika gymnasieskolor från två olika städer i Östergötland skriftligt besvara frågan: "Skulle du vilja ha fler vargar runt i kring området där du i dag bor?". Den första skolan var en större kommunal gymnasieskola, med elever på naturvetar-, teknik-, fordons- och industriprogrammet och den andra en småskalig friskola, med elever på naturvetar- och samhällsvetarprogram, den tredje också en småskalig friskola med elever från enbart naturvetarprogram, den fjärde var en större kommunal skola med elever på samhällsvetar- och medieprogram, och den femte och sista en kommunal skola med framför allt naturvetar- och samhällsvetarprogram. Totalt 352 elever besvarade enkäten. Elevernas svar analyserades kvantitativt för att få en översiktlig bild av hur eleverna ställer sig till frågan om att ha vargar i det område där de bor. Eftersom det finns attitydundersökningar (Karlsson 1999; Karlsson \& Sjöström, 2007) som pekar på att inställningen till varg bland unga människor, som bor i vargrevirfria områden, brukar vara starkt positiv, var en övervägande positiv inställning till varg att förvänta hos gymnasieeleverna, då Östergötland ej har stadigvarande vargrevir. Resultatet från enkätundersökningen användes som underlag för att bestämma sammansättningen av grupperna vid intervjuerna.

\section{Intervjuer}

För att undersöka gymnasieelevers ställningstagande och hur de argumenterar kring vargfrågan användes fokusgruppintervjuer. Enligt Wibeck (2010) kommer, förutom de gruppdynamiska aspekterna som inträder, en bredare skala av idéer fram i en gruppintervju jämfört med en individuell intervju. En huvudtanke med SSI är att använda det informella samtalet mellan olika människor för att ställa olika argument mot varandra, pröva idéer, utbyta information och kunskap med varandra och komma fram till väl underbyggda beslut. För gruppintervjuer utgörs analysenheten främst av gruppen, inte av individen. Det innebär att de argument, ställningstaganden och beslut som gruppen framför, är det resultat som analyseras och jämförs med andra gruppers. För att få ett så stort som möjligt jämförande datamaterial mellan grupper, prioriterades antal grupper i förhållande till antalet gruppmedlemmar. Varje intervjugrupp kom därför att bestå av enbart två elever, som valdes ut efter resultatet av attitydenkätundersökningen. För att eftersträva skillnad i ställningstaganden om vargen, och därmed ge förutsättningar för mer dynamik i pardiskussionerna, placerades elever med motsatta svar tillsammans i grupperna. De elever som valdes ut för intervju utgjordes av de som angivit i enkäten att de var villiga att medverka i en intervju.

Varje intervjugrupp bestod av två elever av samma kön. Totalt intervjuades 9 grupper (18 elever), varav 4 intervjugrupper ( 8 elever, varav 4 pojkar och 4 flickor) bestod av elever på naturvetarprogrammet, 2 intervjugrupper (4 elever, alla flickor) av elever på kombinerat naturvetenskapligt/ 
samhällsvetenskapligt program och 3 intervjugrupper (6 elever, varav 4 pojkar och 2 flickor) av elever på samhällsvetenskapligt program. Eleverna som deltog i intervjuerna var mellan 17 och 18 år gamla och hade precis läst första terminen på sitt andra år på gymnasiet. Alla deltog helt frivilligt och informerades om hur materialet skulle behandlas och vad det skulle användas till.

Gruppintervjuerna var semi-strukturerade i det avseendet att det fanns ett färdigt textmaterial för intervjudeltagarna att ta del av i början av varje intervjusituation samt att intervjun styrdes utifrån några förutbestämda frågor. Under intervjuerna fanns det dock alltid utrymme för en fri diskussion för att kunna studera elevernas interaktioner och argumentation, och kunna fånga upp spontana föreställningar som kunde komma upp under samtalets gång. Huvudfokus för intervjuerna var att få fram elevernas spontana informella argumentation runt en aktuell verklig fråga, utan att eleverna hade haft tid att förbereda sig på ämnet eller fått information om vad arbetet med SSI-frågor generellt innebär.

Inledningsvis presenterades ett kortfattat text- och bildmaterial för eleverna, som skulle ge eleverna en viss inblick i frågan. Texten beskrev vargfrågan och var speciellt fokuserad på att försöka få eleverna att inse vilka problemområden/konfliktsituationer mellan människa och varg som kan finnas. I Karlssons (1999) intervjuundersökning om svenskarnas inställning till varg framkom ett antal "acceptabla motiveringar" för att bedriva vargjakt. De vanligaste motiveringarna var att vargar uppträder oskyggt, tar tamdjur, tar hundar, att människor är rädda, samt att vargen tar älg och rådjur. Med utgångspunkt i dessa fyra motiveringar utformades faktamaterialet till intervjuerna under tre rubriker av konfliktsituationer: Vargangrepp på jakthundar, vargangrepp på människor (där underlag för kategorierna "människor är rädda" och "uppträtt oskyggt" ingår), och vargangrepp på tamdjur (boskap). Under varje rubrik presenterades ett kortfattat faktamaterial i form av tabeller och figurer. Sedan följde den ljudinspelade delen av gruppintervjun med diskussion kring huvudfrågan "Går det att ha varg i bebodda trakter?". Intervjuerna utfördes på en avskild plats i elevernas ordinarie skola, och varje intervju varade 20-30 minuter.

\section{Analys}

Parintervjuerna spelades in (ljudinspelning) och innehållet transkriberades ordagrant. Det transkriberade intervjumaterialet analyserades sedan med SEE-SEP-modellen (Chang Rundgren \& Rundgren, 2010). SEE-SEP kan fungera som ett analysinstrument för att förstå och tydliggöra elevers tankegångar och argumentation angående SSI. Sammantaget kan 18 olika koder genereras utifrån SEE-SEP-modellen (se tabell 1) och användas för att kategorisera och synliggöra elevernas olika ställningstaganden och tankegångar som kommit fram i intervjuerna. Resultat från Christenson et al. (in press), där SEE-SEP-modellen använts, visar att alla de 18 koderna kunde identifieras och att modellen utgör ett fungerande analysinstrument för att undersöka elevers skriftliga argumentation.

Vissa närliggande ämnesområden kan delvis överlappa varandra som exempelvis naturvetenskap (Sc) och miljö-relaterad kunskap (En). Enligt tabell 2 har (En) definierats som miljövetenskap och ekologi, medan $(\mathrm{Sc})$ representerar andra områden inom naturvetenskap och teknik. Skillnaden mellan aspekterna kunskap $(\mathrm{K})$ och personliga erfarenheter $(\mathrm{P})$ kan också behöva förtydligas. Kunskaper (K) har definierats som tydliga uttalanden i form av begreppsanvändning, faktapresentation och resonemang, som vanligtvis utgörs av kunskap inhämtad från skolundervisning, medan personliga erfarenheter $(\mathrm{P})$ handlar om mer uttalat självupplevda situationer och händelser som har upplevts "på nära håll" genom att vederbörande sett, hört, känt eller på något annat sätt berörts på ett personligare plan. För att säkerställa en hög inter-kodarreliabilitet kodade både förste och andre författaren hela intervjumaterialet oberoende av varandra utifrån de kriterier som ställts upp på förhand. Definitionerna för de olika koderna kan ses i tabell 2. Överrensstämmelsen i kodningen mellan förste och andre författaren jämfördes sedan och avvikelser och skillnader $\mathrm{i}$ kodning diskuterades och jämkades för det slutliga resultatet. 
Tabell 1. De 18 olika koderna som genereras från SEE-SEP-modellen (Efter Chang Rundgren \& Rundgren, 2010).

\begin{tabular}{lcll}
\hline Subject areas & $\begin{array}{c}\text { Knowledge } \\
(\mathrm{K})\end{array}$ & $\begin{array}{c}\text { Value } \\
(\mathrm{V})\end{array}$ & $\begin{array}{c}\text { Personal experiences } \\
(\mathrm{P})\end{array}$ \\
\hline Sociology/culture (So) & $\mathrm{SoK}$ & $\mathrm{SoV}$ & SoP \\
Environment (En) & $\mathrm{EnK}$ & $\mathrm{EnV}$ & $\mathrm{EnP}$ \\
Economy (Ec) & $\mathrm{EcK}$ & $\mathrm{EcV}$ & $\mathrm{EcP}$ \\
Science (Sc) & $\mathrm{ScK}$ & $\mathrm{ScV}$ & $\mathrm{ScP}$ \\
Ethics/morality (Et) & $\mathrm{EtK}$ & $\mathrm{EtV}$ & EtP \\
Policy (Po) & PoK & PoV & PoP \\
\hline
\end{tabular}

\section{RESULTAT}

Enkätundersökningen visade att $55 \%$ av gymnasieeleverna uttryckte en negativ inställning till att ha vargrevir i närområdet. En majoritet av flickorna (65 \%) uppgav en negativ attityd, medan en minoritet av pojkarna (44\%) uttryckte en negativ inställning.

I intervjustudien kunde 16 olika koder identifieras ur elevernas intervjusvar (se tabell 2). Kunskap kopplat till etik och moral (EtK) samt personliga erfarenheter från ekonomi (EcP) kunde inte återfinnas i elevernas argumentation i någon av intervjuerna.

Vid analysen genererades totalt (ur 9 intervjuer) 298 argument som var och en tillhör någon av de tre aspekterna kunskap (K), värderingar $(\mathrm{V})$, eller personliga erfarenheter $(\mathrm{P})$ kopplat till något av de sex ämnesområdena samhälle/kultur (So), ekonomi (Ec), miljö/ekologi (En), naturvetenskap/teknik (Sc), etik/moral (Et), och lagar/förordningar (Po). Värderingar kopplat till miljö/ ekologi $(\mathrm{EnV})$ var den kod som i medeltal var vanligast förekommande $(28 \%)$ i samtliga elevers argumentation om vargar i Sverige (se figur 2). Därefter utgjordes $12 \%$ av argumenten av värderingar kopplat till etik/moral (EtV) samt lika mycket (12\%) för kunskap kopplat till naturvetenskap/teknik (ScK). Kunskaper kopplat till miljö/ekologi utgjorde $10 \%$ och värderingar kopplat till samhälle/kultur $9 \%$, av elevernas argumentation. De minst förekommande koderna var EtP (personliga erfarenheter från etik/moral, 0,3 \%), samt PoK och PoP (kunskaper och personliga erfarenheter kopplat till lagar och bestämmelser, 0,3 \%). Kunskaper kopplat till etik och moral (EtK), samt personliga erfarenheter kopplat till ekonomi (EcP) saknades helt (se figur 2).

Oavsett ämnesområde var värderingar (V), den aspekt som eleverna använde mest (60 \%) i sina argument. Kunskaper (K) utgjorde $30 \%$ och personliga erfarenheter (P) enbart $10 \%$ (se figur 3). 
Tabell 2. SEE-SEP-modellens olika koder med exempel från elevernas intervjusvar.

\begin{tabular}{|c|c|c|}
\hline Kod & Definition & Exempel \\
\hline SoK & $\begin{array}{l}\text { Eleven tillämpar begrepp och teorier från } \\
\text { samhällsvetenskap och kultur som stöd för sina } \\
\text { argument. }\end{array}$ & $\begin{array}{l}E_{18}: \text { "Risken att dö i en vargattack rent procentuellt i Sverige är ju } \\
\text { ganska låg. Så då borde man egentligen vara mer rädd för att köra bil } \\
\text { än att gå i skogen till exempel.." } \\
E_{13}: \text { "Det går inte att begränsa och hålla djuren utanför mänskliga } \\
\text { samhället. Det krockar ju någon gång så. Det har alltid varit så typ. } \\
\text { Särskilt när vi nu sprider ut oss så mycket.." }\end{array}$ \\
\hline SoV & $\begin{array}{l}\text { Eleven uttrycker värderingar, affektioner, attityder } \\
\text { med koppling till samhällsvetenskap och kultur, som } \\
\text { stöd för sina argument. }\end{array}$ & $\begin{array}{l}E_{12}: \text { "Regeringen kanske borde få fler människor att engagera sig } \\
\text { inom vargområdet, så att de liksom kan hitta fler lösningar och folk } \\
\text { som kan jobba på och göra saker." } \\
E_{1} \text { : "Men man kan ju inte bara säga att: nej, ni får inte.. som i Kina } \\
\text { med barn till exempel.. ni får inte behålla flickor för då blir vi } \\
\text { överbefolkade. Det är inte riktigt rätt." }\end{array}$ \\
\hline SoP & $\begin{array}{l}\text { Eleven använder och uttalar sina egna personliga } \\
\text { erfarenheter från samhälls- och kulturliv, som stöd } \\
\text { för sina argument. }\end{array}$ & $\begin{array}{l}E_{13} \text { : "Det känns inte som att, jag själv kanske inte är så mycket i } \\
\text { skogen, jag är mest inne i stan och där känns det ganska osannolikt } \\
\text { att en varg kommer gående på gatan liksom." } \\
E_{18} \text { : "Det är som att gå i stan. Då tar du risker att någon kan komma } \\
\text { och slå ner dig eller komma någon och råna dig eller du kan bli } \\
\text { påkörd eller man vet ju aldrig liksom." }\end{array}$ \\
\hline EnK & $\begin{array}{l}\text { Eleven tillämpar begrepp och teorier från } \\
\text { miljövetenskap och ekologi som stöd för sina } \\
\text { argument. }\end{array}$ & $\begin{array}{l}E_{15}: \text { "De har ju djur under sig som dom äter och skulle inte vargen } \\
\text { finnas så skulle det bli för många av dom istället och då kanske dom } \\
\text { skulle bli en fara... }\left(E_{16}: \text { : "För hela ekosystemet rubbas ju då." }\right. \\
E_{18} \text { : "Det finns säkert andra arter som skulle ta över om vi inte skulle } \\
\text { ha varg. Det finns ju en rävpopulation också liksom. Vargen } \\
\text { konkurrerar ju lite med de andra rovdjuren som vi har i alla fall, så } \\
\text { det blir ju ändå en bra balans till slut. Naturen har ju sitt sätt att } \\
\text { balansera upp sig själv.." }\end{array}$ \\
\hline EnV & $\begin{array}{l}\text { Eleven uttrycker värderingar, affektioner, attityder } \\
\text { med utgångspunkter i miljövetenskap och ekologi, } \\
\text { som stöd för sina argument. }\end{array}$ & $\begin{array}{l}E_{3}: \text { "Vi har alltid dödat djur som hotar oss, men idag har vi liksom } \\
\text { förmågan att döda alla vargar och då måste vi känna ett ansvar att } \\
\text { bevara dom istället för att döda allting som hotar oss liksom.." } \\
E_{18} \text { : "Men det är så klart att man förstår att det inte är så kul att veta } \\
\text { att man har en vargflock i sin skog och så har man en massa får till } \\
\text { exempel, och man förlorar får hela tiden. Det är inget roligt. Men det } \\
\text { känns ändå som att vargarna hör ju ändå hemma där. Men det är } \\
\text { klart om jag skulle ha får skulle jag också vilja att vi skjuter alla vargar } \\
\text { sådär, eller det skulle jag inte vilja för jag tycker ändå de hör hemma } \\
\text { där." }\end{array}$ \\
\hline EnP & $\begin{array}{l}\text { Eleven använder och uttalar sina egna personliga } \\
\text { erfarenheter från miljövetenskap och ekologi, som } \\
\text { stöd för sina argument. }\end{array}$ & $\begin{array}{l}E_{9}: \text { "Älgar och sånt är som det är. Det finns mycket av, tycker jag. Jag } \\
\text { har själv skjutit älg och så och jag ser inget problem att det är för lite } \\
\text { av det." } \\
E_{8} \text { : "Jag skulle vara vaksam. Jag skulle inte gå fram och klappa den. } \\
\text { Jag vet inte, jag blev rädd när jag möte vildsvin i skogen. Jag hade ju } \\
\text { gått därifrån." }\end{array}$ \\
\hline EcK & $\begin{array}{l}\text { Eleven tillämpar kännedom om ekonomi och } \\
\text { finanser som stöd för sina argument. }\end{array}$ & $\begin{array}{l}E_{7}: \text { "Om det går, det vet jag inte men, ersättning till dom som } \\
\text { drabbas. För staten insisterar ju på att vargarna ska finnas och då } \\
\text { kanske man kan hitta något sätt att ersätta det där på. Men det } \\
\text { kanske inte alls är möjligt med den dåliga ekonomiska situationen." }\end{array}$ \\
\hline
\end{tabular}




\begin{tabular}{|c|c|c|}
\hline & & $\begin{array}{l}E_{10} \text { : "Men då kanske staten ska lägga pengar på det. Ja, det är ju } \\
\text { också en lösning. Men det är väl fler som sysslar med boskap än varg } \\
\text { så då måste man kanske sätta upp stängsel på många ställen och då } \\
\text { kostar det mycket pengar." }\end{array}$ \\
\hline EcV & $\begin{array}{l}\text { Eleven uttrycker värderingar, affektioner, attityder i } \\
\text { koppling med ekonomiska ämnen, som stöd för sina } \\
\text { argument. }\end{array}$ & $\begin{array}{l}E_{7}: \text { "Det är väl ingenting som säger emot att dom inte ska finnas, } \\
\text { mer än pengavärdet och bönders inkomst kanske." } \\
E_{18} \text { : "Så det skulle ju kunna gå att lösa för det är ju inte så stora } \\
\text { pengar för staten. För det är ju ett sätt som går. För då skulle dom i } \\
\text { alla fall tycka att det känns bättre åtminstone, även om dom inte } \\
\text { känner sig nöjda med sin vargfråga så är det en bättre lösning för alla } \\
\text { liksom." }\end{array}$ \\
\hline EcP & $\begin{array}{l}\text { Eleven använder och uttalar egna personliga } \\
\text { erfarenheter av pengar och ekonomiska system, som } \\
\text { stöd för sina argument. }\end{array}$ & -- \\
\hline ScK & $\begin{array}{l}\text { Eleven tillämpar begrepp och teorier från } \\
\text { naturvetenskap och teknik som stöd för sina } \\
\text { argument. }\end{array}$ & $\begin{array}{l}E_{12}: \text { "Det är viktigt för evolutionen om man ser det så för hundarna } \\
\text { härstammar ju från vargen och om vi hade utrotat vargen för länge } \\
\text { sen så hade vi inte haft några husdjur nu som hundar." } \\
E_{17}: \text { "Det här med tamvargar och sånt, som hade dödat. Om man har } \\
\text { en tamvarg borde man inte släppa lös den i det vilda eftersom den } \\
\text { då är bekant med människan och så vidare, och om du uppfostrar } \\
\text { den fel kanske den tror att den har högre rang än oss människor, och } \\
\text { då är det ju lätt att dom går till anfall." }\end{array}$ \\
\hline ScV & $\begin{array}{l}\text { Eleven uttrycker värderingar, affektioner, attityder } \\
\text { med utgångspunkter i naturvetenskap och teknik, } \\
\text { som stöd för sina argument. }\end{array}$ & $\begin{array}{l}E_{7}: \text { "Om man gör det där vaccinet kanske man kan sätta i någon GPS- } \\
\text { sändare på alla djur så kanske man kan varna folk om det finns } \\
\text { vargar i närheten. Liksom, verka förebygga det på något sätt. Det går } \\
\text { ju givetvis inte att märka alla vargar men en del. Men om man hittar } \\
\text { en så kanske den leder till en annan flock så." } \\
E_{3}: \text { "Borde va nån slags alltså..vetenskapsmän som kollar vilka som } \\
\text { borde liksom dödas om det ska va så, så att det inte blir inavel och } \\
\text { allting." }\end{array}$ \\
\hline ScP & $\begin{array}{l}\text { Eleven använder och uttalar sina egna personliga } \\
\text { erfarenheter från naturvetenskap och teknik, som } \\
\text { stöd för sina argument. }\end{array}$ & $\begin{array}{l}E_{9} \text { : "Jag vet själv hur jakthundar är. Jag var själv på väg att skaffa } \\
\text { jaktlicens, och jag har kompisar och sånt, och under hela min } \\
\text { uppväxt varit med jägare med både.. mestadels fågel, men } \\
\text { jakthundar i sig är ju väldigt aggressiva och uppretande, och vill vara } \\
\text { på nära håll och sen backa. Men just att reta upp... dom vill inte se } \\
\text { gränsen i det naturliga... .att reta upp en varg som är mycket mer } \\
\text { överlägsen i strid så förstår man hur det slutar. På så sätt ser jag } \\
\text { inget allvarligt i att just jakthundar blir skadade.." }\end{array}$ \\
\hline EtK & $\begin{array}{l}\text { Eleven tillämpar begrepp och teorier från etik- och } \\
\text { moralvetenskap som stöd för sina argument. }\end{array}$ & +- \\
\hline EtV & $\begin{array}{l}\text { Eleven uttrycker värderingar, affektioner, attityder i } \\
\text { koppling med etik och moral, som stöd för sina } \\
\text { argument. }\end{array}$ & $\begin{array}{l}E_{13}: \text { "Dom har lika rätt att leva som människor eller hundar eller } \\
\text { grisar eller någonting liksom. Dom var antagligen här före oss } \\
\text { människor antar jag, så liksom djur har mer rätt att leva än } \\
\text { människor, tycker jag." } \\
E_{17}: \text { "Vad värdesätter oss människor mer än ett djur asså? Varför är } \\
\text { vi viktigare? Det är bara egotänkande vi människor har i det fallet." }\end{array}$ \\
\hline EtP & Eleven använder och uttalar sina egna personliga & $E_{10}$ : "Jag som själv uppskattar att vara ute och röra mig i naturen. \\
\hline
\end{tabular}




\begin{tabular}{|c|c|c|}
\hline & $\begin{array}{l}\text { erfarenheter från etik- och moralfrågor, som stöd för } \\
\text { sina argument. }\end{array}$ & $\begin{array}{l}\text { Det skulle jag absolut inte vilja ta ifrån någon annan genom att en } \\
\text { vargflock ska få vara här och utsätta dom för en livsfara." }\end{array}$ \\
\hline PoK & $\begin{array}{l}\text { Eleven tillämpar kunskap om lagar och bestämmelser } \\
\text { som stöd för sina argument. }\end{array}$ & $\begin{array}{l}E_{8}: \text { "Men det jag stör mig på är att man får skjuta } 27 \text { vargar, men det } \\
\text { förekommer illegal vargjakt mellan } 20 \text { och } 25 \text { vargar, så då är det ju } \\
\text { ändå } 50 \text { vargar som ryker varje år av tvåhundra." }\end{array}$ \\
\hline PoV & $\begin{array}{l}\text { Eleven uttrycker värderingar, affektioner, attityder i } \\
\text { koppling med lagar och bestämmelser, som stöd för } \\
\text { sina argument. }\end{array}$ & $\begin{array}{l}E_{10}: \text { "Om det blir ett problem måste man kunna åtgärdat och det gör } \\
\text { ju folk olagligt om de inte får det. Så det tycker jag är onödigt att } \\
\text { dom ska behöva göra. För dom gör ju det för att skydda sin, liksom } \\
\text { om jag har ett företag med bilar, som dom jobbar med boskap, och } \\
\text { så kommer någon och slår sönder mina bilar. Då liksom måste jag få } \\
\text { åtgärda problemet, och det är ju massa pengar som försvinner } \\
\text { genom att vargen bara dödar massa får utan att äta upp det. Så då } \\
\text { tycker jag det är självklart att.... då vill jag helst inte se någon sån här } \\
\text { byråkrati där det tar lång tid att få tillstånd, utan att ganska snabbt } \\
\text { kunna se att här behövs det skjutas lite varg." } \\
E_{7}: \text { "Alltså, jag tycker man kan ta bort den där licensjakten, eftersom } \\
\text { det redan dör så många av illegal jakt. Så det verkar som att } \\
\text { licensjakten inte riktigt behöver finnas." }\end{array}$ \\
\hline PoP & $\begin{array}{l}\text { Eleven använder och uttalar sina egna personliga } \\
\text { erfarenheter angående lagar och bestämmelser, som } \\
\text { stöd för sina argument. }\end{array}$ & $\begin{array}{l}E_{7} \text { : "Jag hörde, jag vet inte om det är sant, men det var någon som } \\
\text { hade får och som såg att en varg höll på att käka upp några där och } \\
\text { då sköt ju han den där vargen då och då blev han bötfälld med } \\
\text { massa pengar. Och så tycker inte jag det ska vara, för är dom ett hot } \\
\text { mot sin boskap så tycker jag man ska kunna jaga dom, men inte om } \\
\text { dom inte gjort något." }\end{array}$ \\
\hline
\end{tabular}

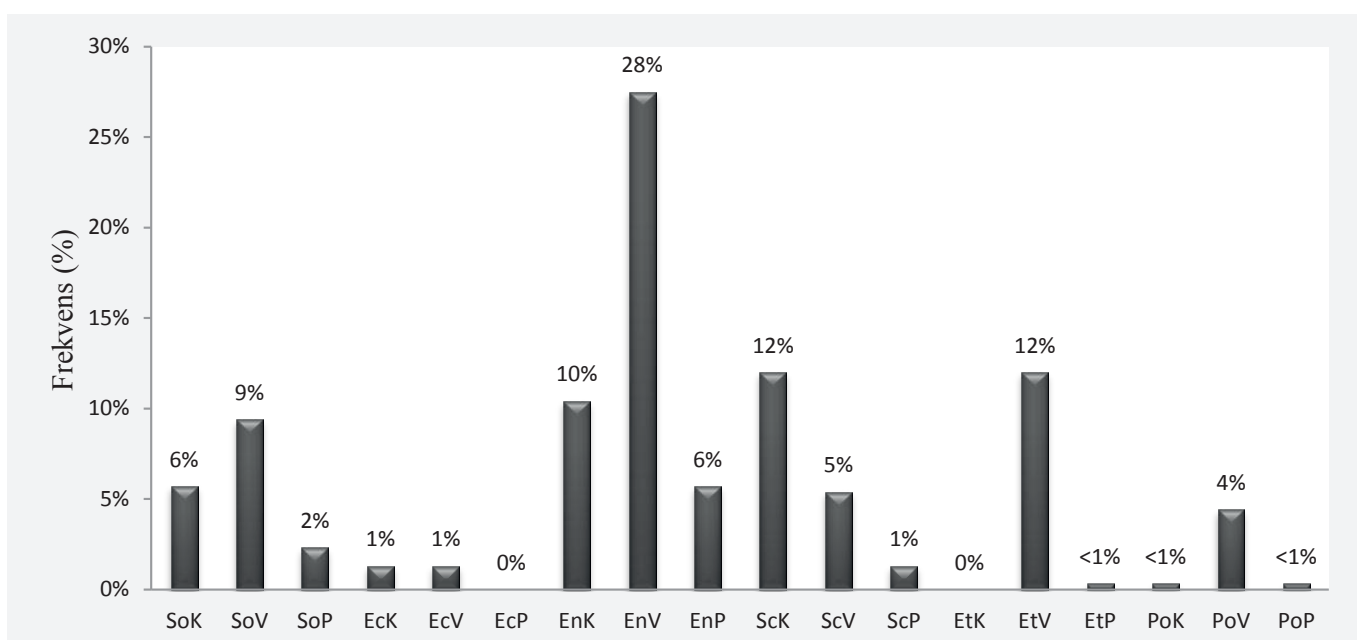

Figur 2. Fördelningen av samtliga intervjuade elevers $(n=18)$ argument $i$ de 18 koderna, enligt SEE-SEP-modellen. Totalt kunde 298 argument detekteras, tillhörande 16 av de möjliga 18 koderna. De sex ämnesområdena är samhälle/kultur (So), ekonomi (Ec), miljö/ekologi (En), naturvetenskap/teknik (Sc), etik/moral (Et), och lagar/ förordningar (Po), och de tre aspekterna är kunskaper (K), värderingar (V), och personliga erfarenheter $(P)$, enligt SE E-SEP-modellen. 


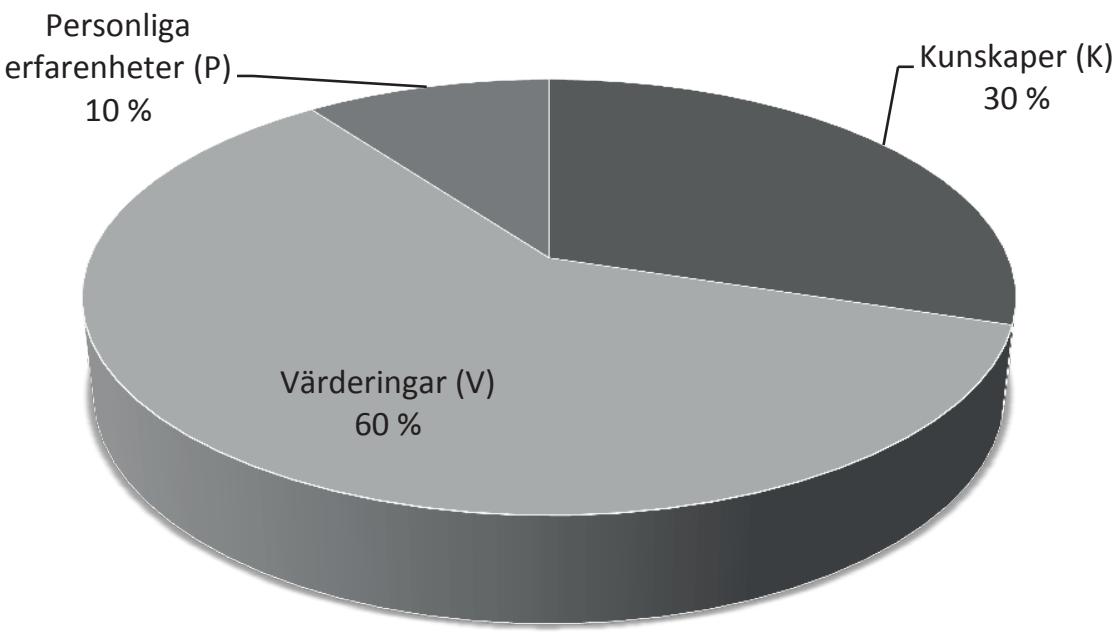

Figur 3. Fördelning i medeltal av KVP hos samtliga el evers $(n=18)$ argumentation. Genom analys av 18 elevers argumentation vid nio olika parintervjuer hittades 298 argument tillhörande de tre aspekterna kunskaper $(\mathrm{K})$, värderingar $(\mathrm{V})$, och personliga erfarenheter $(\mathrm{P})$, enligt SEE-SEPmodellen.

\section{Diskussion}

Av de 352 gymnasieelever som besvarade enkäten svarade $55 \%$ att de inte skulle vilja ha fler vargar i området där de själva bor. Detta kan jämföras med resultatet i Karlssons (1999) intervjuundersökning där 2000 slumpmässigt utvalda svenskar tillfrågades om de kunde acceptera att ha varg i närheten där de bor. Av alla intervjuade uppgav $43 \%$ att de inte kunde acceptera att ha varg i närheten av platsen där de bodde. Detta är till synes en mindre andel än vad som visats i denna studie, dock är frågan i Karlssons (1999) undersökning och denna enkätundersökning aningen olika formulerade. Det kan vara skillnad på att besvara frågan om du kan acceptera vargar i närheten där du bor, som frågades i Karlssons studie, jämfört med att svara på om du skulle vilja ha fler vargar i kring där du bor, vilket var frågan som ställdes i denna studie. Karlsson (1999) har också noterat att ålder och kön spelar en stor roll för inställningen till varg. För åldersgruppen 15-29 år svarade nämligen endast $26 \%$ av männen och $44 \%$ av kvinnorna att de inte kunde acceptera varg i närheten där de bor, jämfört med denna studie där $44 \%$ av pojkarna och $65 \%$ av flickorna tyckte det var positivt att det inte finns fler vargar i kring där de bor. Att kön har betydelse för attityden till varg och andra rovdjur har framkommit i ett flertal större undersökningar (Karlsson, 1999, Linell \& Bjerke, 2002). Linell \& Bjerke (2002) sammanfattar resultat från flera skandinaviska studier som visar att kvinnor verkar känna mer oro för varg och uttrycker generellt en större rädsla för olika rovdjur.

I resultaten från tidigare studier (Christenson et al., in press) har SEE-SEP-modellen visats vara ett fungerande analysinstrument för analys av gymnasieelevers informella argumentation i skrivna uppsatser. Resultaten i denna studie tyder på att SEE-SEP-modellen även är ett lämpligt analysinstrument för analys av muntlig informell argumentation i intervjuer. Elevernas argument kunde enligt SEE-SEP-modellens definitioner (se tabell 2) kodas i 16 olika koder fördelade på de tre aspekterna KVP. Ibland kan skillnaden mellan de tre aspekterna KVP bli något otydlig, då de olika aspekterna i vissa fall kan överlappa varandra. Ett kunskapsargument kan ibland samtidigt också vara värderande och personliga erfarenheter kan också uttryckas i form av kunskap. Det finns problem och begränsningar med alla modeller och SEE-SEP-modellen är givetvis inget undantag, men styrkan i modellen är ändå dess tydlighet i åskådliggörandet (och möjlighet till kvantifierande) av de tre aspekterna KVP, som tidigare till stor del saknats i studier inom detta område. 
I ljuset av det tidigare nämnda multiperspektivet i aktuella naturvårdsfrågor, där flera olika aspekter måste vägas in, samt den här genomförda analysen med SEE-SEP-modellen av elevernas argumentation i frågan om att bevara vargar i Sverige, verkar naturvårdsfrågor om artbevarande vara en lämplig kontext för SSI-undervisning. Ratcliffe \& Grace (2003) har konstaterat att bilden är oklar om hur stor betydelse kunskaper i biologi verkligen har i bevarandefrågor och belyser att de etiska, estetiska, kulturella och andra värdegrundade faktorer kanske egentligen är lika väsentliga, eller t.o.m. viktigare för beslutsfattande om vad som ska bevaras och inte. Därför är det inte oväntat att elevernas argumentation till stor del visade sig grundas på värderingar, speciellt inom miljö och ekologi (EnV). Grace \& Ratcliffe (2002) konstaterade också i sin studie om bevarande av elefanter och lunnefåglar att värderingar spelar en stor roll i argumentationen, och har en tendens att bli allt mer framträdande vartefter diskussionen fortgår. Grace (2009) poängterar även att ibland kan värderingar och naturvetenskapliga begrepp vara svåra att skilja åt i naturvårdsfrågor. Konkurrens mellan arter är ett biologiskt begrepp, men konkurrens mellan djur och människor kan också betraktas som en värderingsfråga beroende på ur vilket perspektiv frågan betraktas. I Christenson et al.:s (in press) studie, där gymnasieelevers skriftliga argumentation från fyra SSI med olika kontexter (global uppvärmning, GMO, kärnkraft och konsumtion) analyserades, visade sig också störst andel argument vara grundade på EnV.

Ett nämnvärt resultat är även att eleverna har få argument kopplade till lagar och förordningar (Po) samt ekonomi (Ec), trots det faktum att lagar om jakt och naturskydd, konventioner om artbevarande och ekonomiska frågor rörande bidrag och ersättningar för viltskador och rovdjursangrepp, är centrala begrepp i vargdebatten. Lee \& Grace (2010) konstaterar också i sin studie om en SSI-fråga som berör bevarande av fladdermöss att elever inte verkar vara tillräckligt medvetna om de lagar och bestämmelser som skyddar djur- och växtliv. Även i studier av Mork (2006) och Christenson et al. (in press) uppvisar elever brister i att använda argument som bygger på både lagar/bestämmelser och ekonomi. Lärare bör därför vara särskilt uppmärksamma på att elever tar hänsyn till just de ämnesområdena vid diskussioner om hållbar utveckling och bevarande av biologisk mångfald.

En invändning mot resultatet som visar vilka olika ämnesområden eleverna hämtade sina argument ifrån skulle kunna vara att deras ställningstaganden kan ha färgats av den information som presenterades i inledningsfasen av varje intervju. I ett fall där eleverna, exempelvis under ett längre projekt, själva får söka information, som de bedömer som relevant i frågan, kanske en annan fördelning av olika argument framkommer. Den ringa storleken på fokusgrupperna är också något att ta i beaktande. Det kan inte helt uteslutas att ett större antal gruppdeltagare kan påverka möjligheterna för fler olika argument att framträda och utvecklas i en diskussion.

Flera tidigare studier (Ekborg, 2002; Sadler \& Donnelly, 2006) har inriktat sig på kunskapsaspekten och försökt finna ett samband mellan en individs relevanta ämneskunskaper och förmågan att argumentera och tillämpa dessa kunskaper för genomtänkta ställningstaganden i olika SSI-frågor. Resultat från dessa studier visar förvånansvärt nog att kopplingen mellan kunskaper och användande av kunskaper i resonemang och kvalitet på argumentation inte är entydig. I den föreliggande studien utgjorde argument som baseras på kunskapsaspekten bara en knapp tredjedel av alla argument, medan argument byggda på värderingar var i klar majoritet med ungefär dubbelt så stor andel. Detta resultat stöds av dels tidigare studier med samma analysinstrument (Christenson et al., in press), men också i andra typer av studier (Ekborg, 2002; Grace \& Ratcliffe, 2002; Sadler \& Zeidler, 2005). Vid en informell argumentering i en SSI-fråga verkar fördelningen av KVP vara relativt stabil i olika sammanhang. Ska detta tolkas som att användning av kunskaper respektive värderingar är oberoende av undervisningen, och att kvaliteten och omfattningen av undervisningen inte nämnvärt påverkar detta förhållande? Eftersom hittills genomförda analyser med SEE-SEP-modellen enbart tillämpats på gymnasieelevers argumentation vore det intressant att analysera fördelningen av KVP för andra grupper i samhället, t.ex. högskolestudenter, lärare, politiker etc. Går det att finna samma fördelning av KVP inom dessa grupper? 
Genomgående i SSI-litteraturen framhålls betydelsen av att uttrycka känslomässiga värderingar och etiska och moraliska ställningstaganden i sociovetenskapliga dilemman (Ekborg, 2002; Grace, \& Ratcliffe, 2002; Sadler \& Zeidler, 2005). Ekborg (2002) framhåller att det är lika farligt att bygga argumentation på enbart kunskaper i naturvetenskap och teknik som det är att endast bygga dem på attityder, känslor och värderingar. Många belyser också vikten av att tillåta att emotioner och värderingar kommer till uttryck i NO-undervisningen och att etiska, moraliska och känslomässiga resonemang måste få ha sitt utrymme även inom de naturvetenskapliga ämnena (Sadler \& Zeidler, 2005). Fördelningen av KVP kan också tolkas som ett incitament att uppmärksamma värderingar i NO-undervisningen, eftersom uttryckandet av värderingsargument verkar vara så betydelsefullt i elevernas argumentation i SSI-frågor. Om NO-klassrummet sätter upp ramar som inte tillåter eller värdesätter emotioner och värderingar kan många elever uppleva sig begränsade i sina resonemang och få en negativ bild av naturvetenskap som något alltför rationellt, känslokallt, opersonligt och tråkigt. Sadler \& Zeidler (2005) konstaterar att förekomst och utrymme för intuitiva reaktioner, emotioner, och personliga resonemang kan vara avgörande länkar för att nå elevernas personliga intressen och väcka deras personliga engagemang för naturvetenskapliga frågeställningar. Men oavsett inslag av många värderingsargument så kvarstår frågan varför eleverna använder så relativt få argument som byggs på kunskap i sina resonemang i SSI-frågor. Även om den föreliggande studien inte haft som huvudfråga att undersöka kvaliteten på elevernas argument och resonemang, kan i en översiktlig kvalitativ analys, ändå en avsaknad av vissa naturvetenskapliga resonemang och begrepp märkas. Resonemang om ekologiska aspekter som näringsvävar och populationsekologiska samspel är exempelvis sällsynta och i de fall de förekommer mycket kortfattade. Sadler \& Donnelly (2006) gav tre förklaringar till varför de inte kunde se ett samband mellan kunskapsnivå och kvalitet på argumentationen: 1) Eleverna kanske inte tänker på att använda naturvetenskaplig kunskap, framför allt den kunskap de fått i skolan, i en SSI-kontext, 2) problemet handlar inte om tillämpningen av naturvetenskaplig kunskap utan snarare brist på förståelse av mer specifik kunskap, eller 3) det finns ett samband mellan kunskapsnivå och kvalitet på argumentationen, men att det sambandet inte är linjärt (the threshold model of knowledge transfer). Varför eleverna inte använde mer biologikunskaper i sina argument och resonemang i just SSI-frågan om vargar i Sverige, är svårt att entydigt besvara. Det kan givetvis bero på att eleverna saknar för SSI-frågan relevanta biologikunskaper. Men en troligare förklaring är att eleverna har relevanta kunskaper men har svårigheter att tillämpa dem i andra sammanhang, speciellt i mer verklighetsbaserade frågor. Förutom problem med tillämpning av kunskapen i olika kontexter, kan den bristande andelen kunskapsargument också bero på att eleverna generellt har svårt att verbalt kommunicera naturvetenskap och är ovana att argumentera utifrån naturvetenskaplig kunskap.

Hur undervisningen kan påverka elevernas användande av kunskaper i olika samhällsfrågor är fortfarande en öppen fråga. Det vore av stort intresse att genomföra fler studier där olika former av SSI-undervisning används och elevernas argumentation analyseras. I denna studie har huvudfokus inte varit att analysera kvaliteten på elevernas olika argument, men det råder inget tvivel om att olika argument kan befinna sig på olika kvalitetsnivåer. Här behövs fler studier, som gärna också kan knytas till SEE-SEP-modellens analytiska ramverk, för att ytterligare utreda hur KVP förehåller sig till skolundervisningen samt hur olika nivåer av kvalitet på argument kan framträda i resonemang kring SSI-frågor. SEE-SEP-modellen skulle även kunna användas för att analysera argumentation kring SSI inom andra områden, exempelvis hälsa och val av livsstil, vilka knyter an till vardagliga val och beslutsfattande som eleverna har lätt att relatera till i sina egna liv. SEE-SEPmodellen har nyligen också använts för design av undervisning kring SSI (Chang Rundgren, 2011b).

\section{TACK}

Slutligen vill vi rikta ett stort tack till alla som på ett eller annat sätt varit involverade i detta projekt: till Daniel Orraryd, Mats Lind, Peter Lindström m.fl. för er hjälp med enkäter och elevunderlag, till alla elever som svarade på vargenkäten och speciellt till dem som så frikostigt ställde upp som deltagare i vargintervjuerna. 


\section{REFERENSER}

Aikenhead, G. (1994). What is STS in science teaching? In: J. Solomon \& G. Aikenhead (Eds.) STS education: International perspectives on reform. New York: Teachers College Press.

Chang Rundgren, S.-N. (2011a). How does background affect attitudes to socioscientific issues in Taiwan? Public Understanding of Science, 20 (6), 722-732.

Chang Rundgren, S.-N. (2011b). Post it! - A cross-disciplinary approach to teach socioscientific issues. Teaching Science, 5 (3), 25-28.

Chang Rundgren, S.-N. \& Rundgren, C.-J. (2010). SEE-SEP: From a separate to a holistic view of socioscientific issues. Asia-Pacific Forum on Science Learning and Teaching, 11 (1).

Christenson, N., Chang Rundgren, S.-N \& Höglund, H.-O. (in press). Using the SEE-SEP Model to Analyze Upper Secondary Students' Use of Supporting Reasons in Arguing Socioscientific Issues. Journal of Science Education and Technology Online First DOI 10.1007/s10956-0119328-x

Clement, P. (2004). Science et idéologie: exemples en didactique et épistémologie de la biologie. Actes du Colloque Sciences, médias et société, 53-69. Retrived September, 29, 2011, from ENA-LSH (Ecole normale supèrieure Lettres et Sciences humaines, Lyon) Web site http:// sciences-medias.ens-lsh.fr

Clement, P. (2006). Didactic Transposition and the KVP Model: Conceptions as Interactions Between Scientific Knowledge, Values and Social Practices. Proceedings Summer School ESE RA, 9-18. IEC, Univ. Minho, Portugal.

Driver, R., Newton, P., \& Osborne, J. (2000) Establishing the norms of scientific argumentation in classrooms. Science Education 84 (3), 287-312.

Ekborg, M. (2002). Naturvetenskaplig utbildning för hållbar utveckling? Göteborg: Göteborgs universitet.

Grace, M. M., \& Ratcliffe, M. (2002). The science and values that young people draw upon to make decisions about biological conservation issues. International Journal of Science Education, 24 (11), 1157-1169.

Grace, M. (2009). Developing high quality decision-making discussions about biological conservation in a normal classroom setting. International Journal of Science Education, 31 (4), 551570.

Karlsson, J. (1999). Svenskarnas inställning till varg - en intervjuundersökning. Grimsö forskningsstation.

Karlsson, J. \& Sjöström, M. (2007). Human attitudes towards wolves, a matter of distance. Biological conservation, 137 (4), 610-616.

Kolstø, S. D. (2001). "To trust or not to trust..." -pupils' ways of judging information encountered in a socioscientific issues. International Journal of Science E ducation 23 (9), 877-901.

Lee, Y. C., \& Grace, M. (2010). Students' reasoning processes in making decisions about an authentic, local socio-scientific issue: bat conservation. Journal of Biological Education, 44 (4), 156-165.

Linell, J. D. C. \& Bjerke, T. (2002). Rädslan för vargen - en tvärvetenskaplig utredning. Viltskadecenter, Grimsö forskningsstation.

Millar, R. (2008). Taking scientific literacy seriously as a curriculum aim. Asia-Pacific Forum on Science Learning and Teaching, 9 (2).

Mork, S. M. (2005). Argumentation in science lessons: Focusing on the teacher's role. NorDiNa 1 (1), 17-30.

Mork, S. M. (2006). ICT in Science Education. Exploring the Digital Learning Materials at viten. no. $\mathrm{PhD}$ thesis in Science Education. University of Oslo.

Ratcliffe, M., \& Grace, M. (2003). Science Education for Citizenship. Teaching Socio-Scientific Issues. Maidenhead: Open University Press.

Rundgren, C.-J., Chang Rundgren, S.-N., Lin, P-L, Tseng, Y. H., \& Chang, C-Y (in press). Are you SLiM? - The Development of an Instrument for Civic Scientific Literacy Measurement (SLiM) Based on Media Coverage. Public Understanding of Science. Online First DOI $10.1177 / 0963662510377562$ 
Sadler, T. D., \& Zeidler, D. L. (2005). Patterns of informal reasoning in the context of socioscientific decision-making. Journal of Research in Science Teaching, 42 (1), 112-138.

Sadler, T. D., \& Donnelly, L. A. (2006). Socioscientific argumentation: The effects of content knowledge and morality. International Journal of Science Education, 28 (12), 1463-1488.

Sadler, T. D., Barab, S. A., \& Scott, B. (2007). What do students gain by engaging in socioscientific inquiry? Research in Science Education, 37 (4), 371-391.

Sandström, C., Ericsson, G. (2009). O m svenskars inställning till rovdjur och rovdjurspolitik. Rapport 2009:1, Inst. för vilt, fisk och miljö, Umeå: SLU.

Shamos, M. H. (1995). The myth of scientific literacy. New Brunswick, NJ: Rutgers University Press.

Svensson, L. \& Hedmark, E. (2010). Varg i Sverige vintern 2009/10 - Preliminär statusrapport. Inventeringsrapport från Viltskadecenter, Grimsö forskningsstation.

Zeidler, D. L., Sadler, D.T., Simmons, M.L., \& Howes, E. V. (2005). Beyond STS: A research based framework for socioscientific issues education. Science Education, 89 (3), 357-377.

Wibeck, V. (2010). Fokusgrupper - om fokuserade gruppintervjuer som undersökningsmetod. Lund: Studentlitteratur. 